\title{
The Role of Art Museums - the Finnish case
}

MARJA-LIISA RÖNKKÖ*

\begin{abstract}
This article is one part of an ongoing process to collect the entire history of Finnish Museums to be published in 2010. It has it roots in my dissertation ${ }^{1}$ about our art museums' buildings. The final presentation will widen to consist of all kinds of museum buildings and also reflect on relationships between architecture, collections and exhibition design. Unlike many European countries in the first decades of the nineteenth century, Finland - then a Grand Duchy in the Russian Empire - did not posses the basic infrastructure of the art world, such as public collections, an art academy or organized trade in works of art. The field of art began to take shape, in practice, around the Finnish Art Society, which was founded in 1846. 'It was at first a kind of public collector in addition to the University, founded in 1640. The art museum sector was a forerunner in the museum field and it also created both the classical and modern prototypes for the ideal museum building in Finland.
\end{abstract}

Key words: Art museum, modern museum, political museum, Acropolis, Alvar Aalto, "white cube".

The Finnish society aimed to present the narrative of art as fully as possible, and thus associated itself with the prevailing Hegelian tradition of narrative construction that was characteristic of German museums in particular, and it was inspired by a strong Enlightenment ideology. The societies of fine and applied arts got their permanent premises in 1887 in the Ateneum, which also was one of the first museum buildings in Finland. Today, the number of museums dedicated to art, architecture and design is around 80.

When the integration of Europe began to achieve concrete forms in 1990s, cultural heri- tage became a core theme, involving as it did the role and survival of the culture and identity of Europe in the world. The special role of museums in maintaining the cultural heritage was also noted. In this connection, the Nordic Council of Ministers made a surprising discovery in 1993: the word museum was not mentioned once in its recently approved ten-year plan. Only indirect reference to museums could be inferred in certain connections, for example under the headings of education and the arts. The Council of Ministers appointed a team of experts to study the contemporary role of museums, upon whose recommenda- 


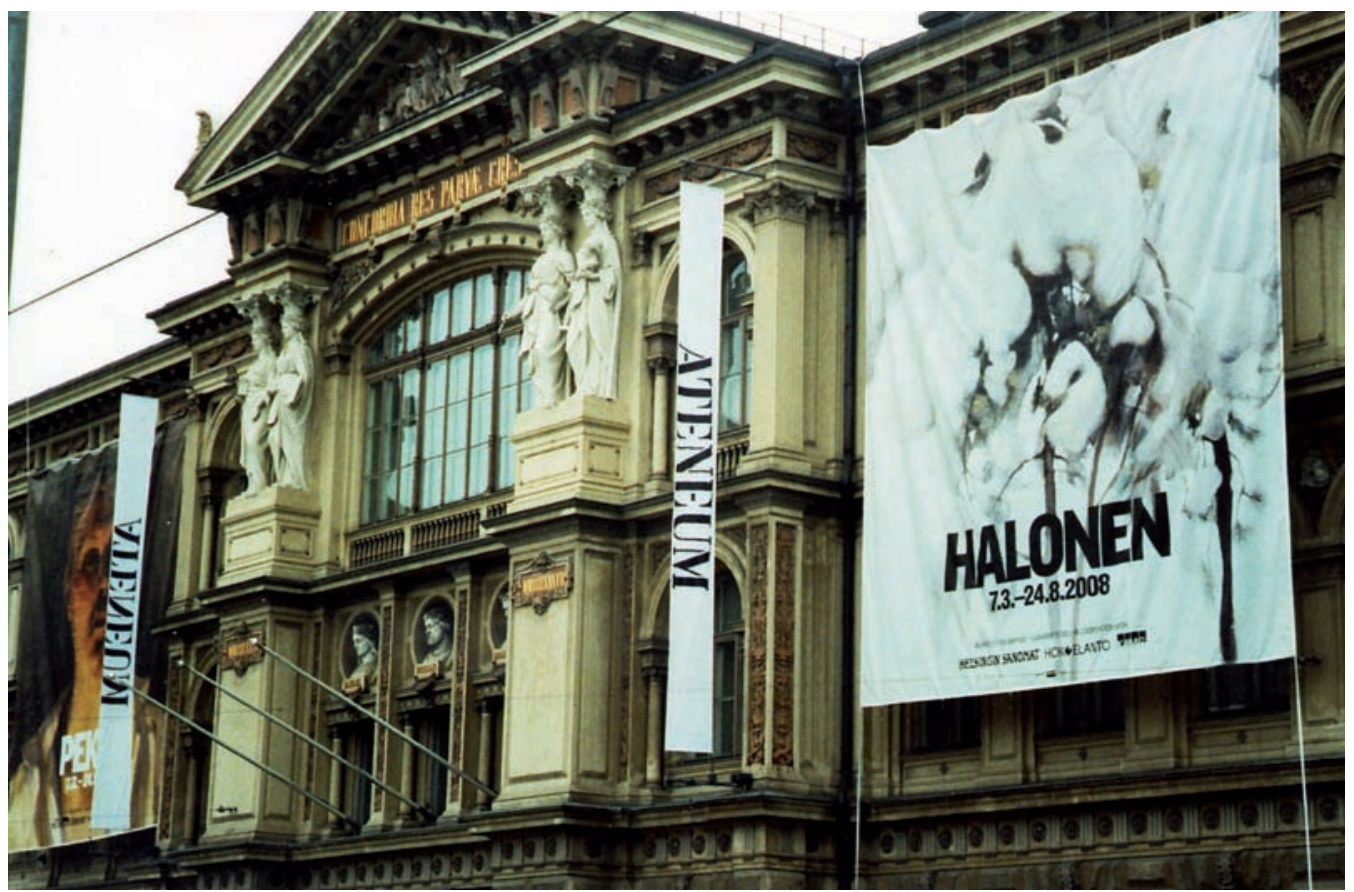

The Ateneum Art Museum, Helsinki. Architect Theodor Höijer, 1887. Photo: Marja-Liisa Rönkkö.

tion a permanent museum committee was established. It appears that the role and status of museums have since then been taken for granted in the Nordic countries, where the modern type of museum evolved and where one of the world's oldest international organizations in the field, the Scandinavian Museums Association, was founded in 1915.

Broader discussion on the cultural heritage is associated with concerns over the musealization of Europe being made into one large outdoor museum. The term cultural heritage refers to reality that has achieved museum status and quality. This musealization, however, does not appear to involve a naturally formed heritage. Rather, it is an explicit legacy, created and passed on through selection, thesauration, presentation and communication as a cultural image.

In Finland, professional museum work is half a century younger than in central Europe - 140 years old to be exact, if we take the country's first art museum curator Berndt Otto Schauman (curator of the society's collection 1869-87) as the starting point. Here, too, the early stages were associated with academic instruction in the culture of antiquity, aesthetics and classical languages and literature in the 1830s-1850s. Suomen Ihannes-Yhistys (the Finnish Art Society) accepted artists and writers as members and also became the kernel of the art museum institution in Finland. 


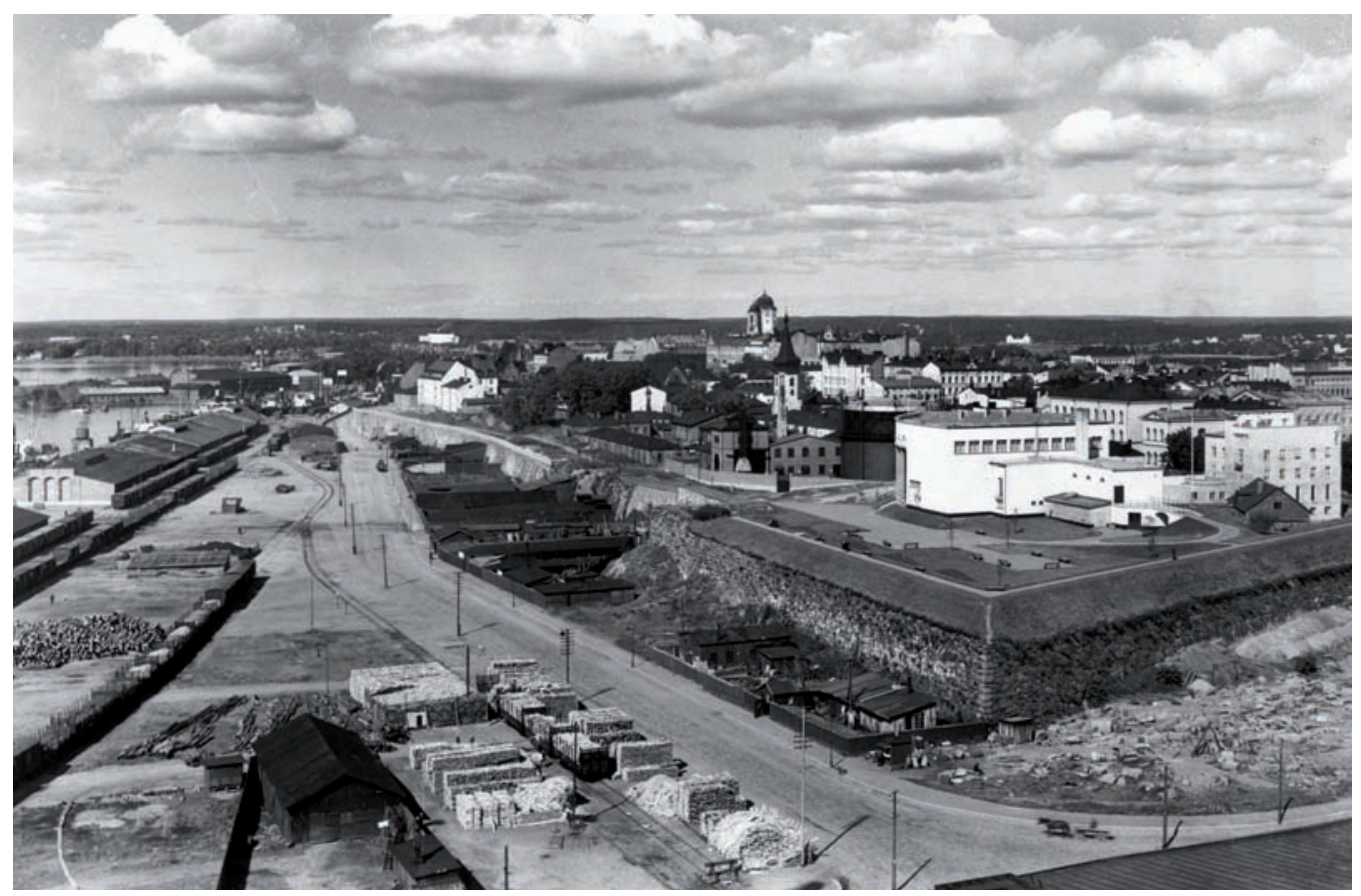

The Viipuri Art Museum, now in Russia, is a veritable Acropolis, a masterpiece in the Nordic classicism. Architect Uno Ullberg, 1930. Photo: The Museum of Finnish Architecture / Roos.

The central art museums of the Nordic countries were established around the same time in the late nineteenth century. Already at that stage there was talk about the outmoded nature of the museums, the tiredness of the public with the museums, in a phenomenon called museum fatigue, and the need for reform in this field. Despite the wishes of Fredrik Cygnaeus (1807-1881), the first Professor of Aesthetics at the University of Helsinki, Finland did not come to have a traditional academy of fine arts but rather a palace of art and industry, which was the idea of Carl Gustaf Estlander (1834-1910), the successor to Cygnaeus as professor. This was more closely suited to the needs of a society on the path of industrialization and modernization. Since then, there has been continuous talk about the unity of architecture, visual arts and applied art, and in general terms of a more integrated and synthesis-oriented ideal for museums, although the tendency of classification and specialization inherent to the museum institution has been so prominent until now that, for example, recent and contemporary art are kept apart from the history of art.

The year 1930 can be taken as a turning point for the museum of the modernist era. It was preceded in the 1910s and 1920s by discussion - in Finland also - of the ideal museum and the special nature and position of art museums. In his 1920 pamphlet $\mathrm{Nya}$ mu- 
seer (New Museums), the Swedish art historian Gregor Paulsson spoke of the "quality museum" and noted that the task of the art museum is to foster the tastes of the masses. In Finland, the architect Gustaf Strengell (18781937) had renewed the exhibitions of the $\mathrm{Mu}-$ seum of Applied Arts in 1912 and the Ateneum in 1915 in this spirit. The year 1930 saw the completion of the Viipuri Art Museum, the pinnacle of contemporary elegance and a veritable Acropolis. A fundamental international achievement was the founding in 1929 of New York's Museum of Modern Art. (MoMA) new building in Manhattan, which was completed in 1939. The fostering of tastes continued with marked emphasis until the 1950s, when a popular education section on the side of Ateneum was established by the foundation of the Fine Arts Academy of Finland.

The most marked developments in Finnish museums took place in the period from the 1960 s to the 1980s. Before the Second World War, there had been half a dozen museums of art in Finland, and only a dozen or so in the 1950s, so the biggest growth has happened after the war. The "Big Bang" in terms of Finnish museums, whose results are only now emerging, took place around. 1970, at about the same time as the visual arts adopted the term post-modern from literature. In architecture, change was expressed in the transparent glass pavilion of the Neue Nationalgalerie in Berlin, which again sought a total revision of the museum concept. In Finland, the most important debate on museum policy and related philosophy lasted from the mid-1960s to the middle of the 1970s. The ideal laid down in these exchanges of opinion was realized to the full in Kiasma, the new museum of contemporary art opened in Helsinki in May

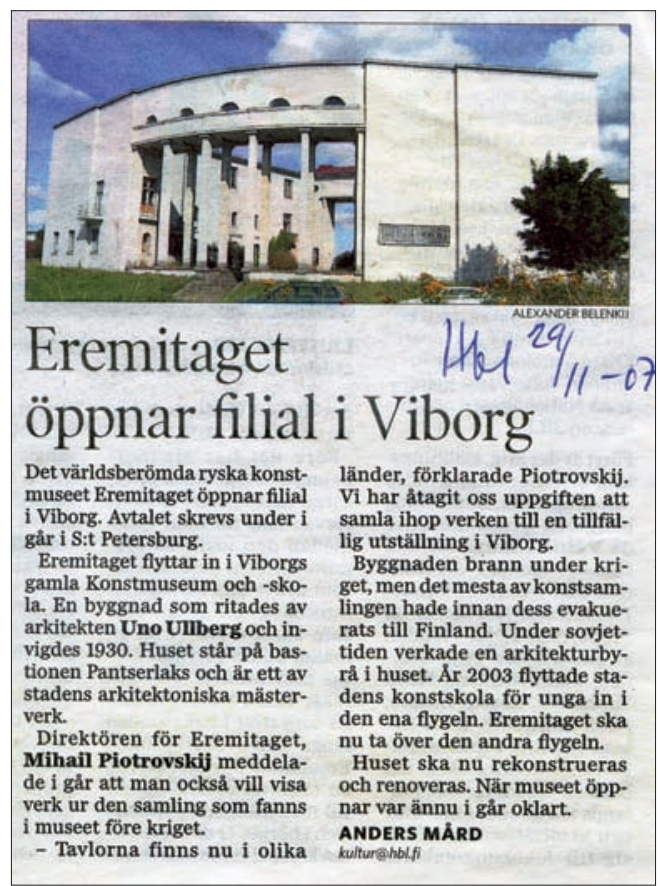

133

The Viipuri Art Museum is returning back to its original purpose, now as a department of the State Hermitage Museum of Russia. The newspaper Hufvudstadsbladet, 3 Nov. 2007.

1998. This was the "plaza of all opportunities", as envisioned at the time.

The first stage of the profession, the founding of museums until the 1920s, had a scholarly emphasis. In the second formative, stage, committed academics with a wide range of skills took control of the museums. These included women. Throughout the period of change from the 1960s to the present day, the professionals of museum work have been reformers and specialists. The fourth generation, which has now taken on the work, is working with the challenges of the new millennium and the information society. 

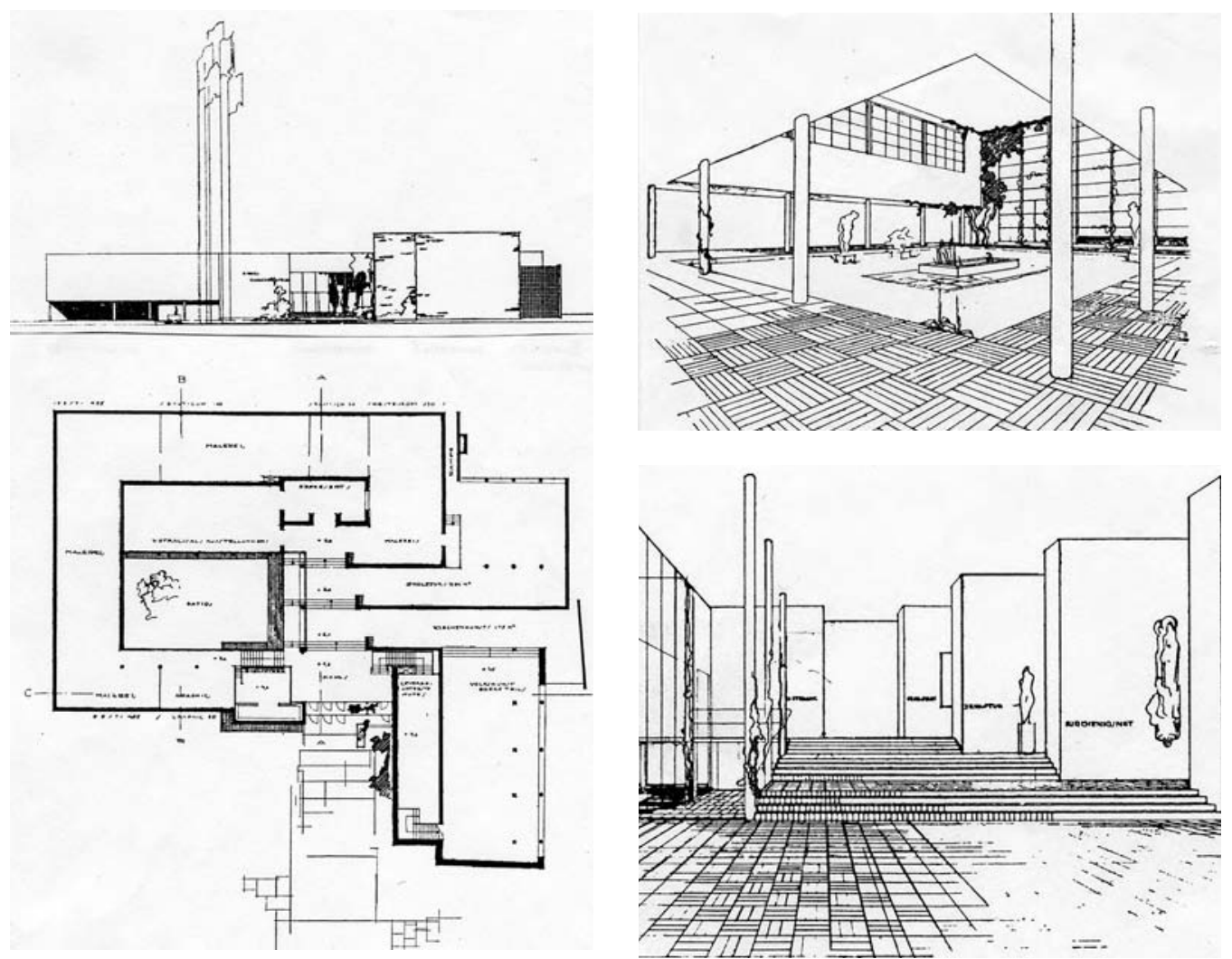

Alvar Aaltos proposal for the Tallinn Art Museum in 1937 did not win, but became a model for museums in Finland. Published in the magazine Arkkitehti 3/1937.

In the art museums, the historical course of development was such that the executive positions went to academics from the very beginning. It has been customary until the 1990 s for the central museum to be headed by a person with a doctorate on an important theme or figure in the history of Finnish art. On the other hand, until the 1960s Finland's other art museums were generally headed by artists, and sometimes by architects. The country's art museums have only had their first or second professionally trained museum directors, a fact that is reflected in current discourse. The so-called museum professionals have had to establish their own place in a field previously dominated by scholars and artists. Museum work today is based above all on experience and intuition; the educational basis for it has been until lately relatively limited.

Since the nineteenth century, a special feature of Finnish culture has been the participation, at least nominally, of key figures in government administration in the societies, associations and other organs furthering cultu- 


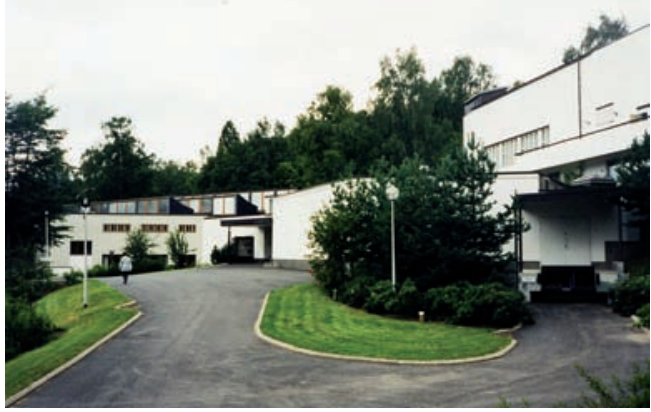

The Museum of Central Finland (1961, on the right) and the Alvar Aalto Museum (1973) in Jyväskylä were designed by Aalto himself, the gallery view is from Aalto Museum. Photos: Marja-Liisa Rönkkö.

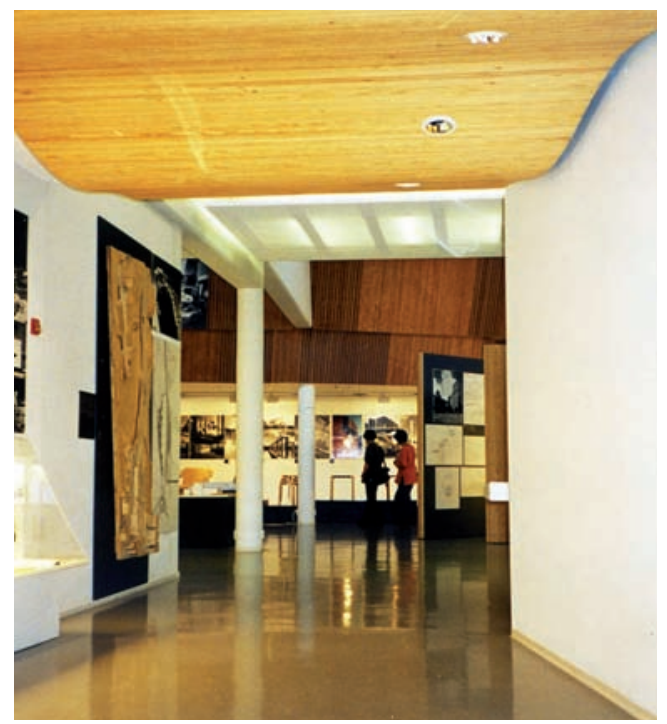

135 ral pursuits in Finland on behalf of the state and with its support. In the nineteenth century, Tsar Alexander II purchased and donated the most significant private art collection in Finland to serve as the nest egg of the national gallery. Professor and Senator Leo Mechelin, who was also chairman of Helsinki's first city council, saw it as a point of honour to influence the imposing exterior architecture of the Ateneum building. Mechelin was also chairman of the Fine Arts Society during the years of Russian oppression around the turn of the nineteenth and twentieth centuries. Julius Ailio (1897-1933), head of the Department of Prehistory of the National Museum of Finland, was not only the first chairman of the Finnish Museums Association, but also Minister of Education as a member of the Social Democratic Party. Marshal C.G. Mannerheim appointed the painter Akseli Gallen-Kallela to be his personal aide-de-camp in 1919. When the Kiasma museum was under construction, the executives of the Helsinki city administration and the prime minister himself were drawn into a heated debate about the museum's location. In connection with the municipal museums, a reflection of this attitude can be seen in the marked commitment of local city administration to municipal art museum projects.

If we accept the definition that a collection becomes a museum when it is regularly open to the public, premises suitable for exhibition use are indispensable in creating a museum. The majority of museums have been housed in old buildings. Finland's first real art museum buildings date from 1887, 1904 and 1930, but most have been built since 1960 . The most recent art museum architecture in particular communicates the new position of museums as generators and barometers of culture.

The relationships between architecture and art on the one hand, and the museum institu- 

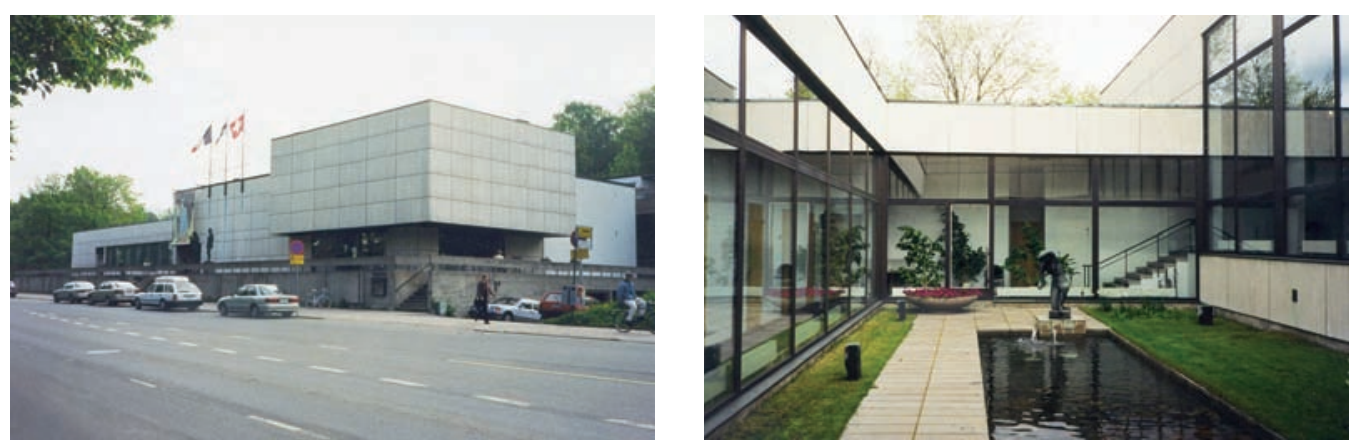

The museum dedicated to sculptor Wäinö Aaltonen in Turku was the first art museum built after the Second Word War. Architects Irma and Matti Aaltonen, 1967. Photo: Marja-Liisa Rönkkö.

tion on the other, have been much written about and discussed in the twentieth century. Art museums are an interesting subject for design precisely because of their almost unclassifiable, unconventional and flexible nature. The design of a museum building can easily be given as a final assignment for students and may also form a building block in the planning of larger cultural centres, as if it were an addition or a culmination.

In Finland, it has become clear that the spirit of the architect Alvar Aalto (1898-1976) hangs over Finnish museums. He was already interested in museum architecture in the 1920s and participated in museum design competitions from the 1930s on. He also designed the first Finnish museum to be built after the Second World War - the Museum of Central Finland in Jyväskylä in 1961. Aalto designed a total of ten museum buildings, of which three were built. In addition to the one just mentioned, he also designed the Alvar Aalto Museum in Jyväskylä (1973) and Aalborg Art Museum in Denmark (1958-1973). Aalto had an active interest in visual art and even painted as a hobby. $\mathrm{He}$ was particularly interested in traditional Finnish folk buildings.
In the period 1960 to 1990 , six independent art museum buildings had appeared, ten had been accommodated in different cultural and commercial centres, and half a dozen old museum buildings were extended with new wing buildings. The six new art museums are, in addition to the above-mentioned Alvar Aalto $\mathrm{Mu}$ seum, the Wäinö Aaltonen Museum in Turku (1967, architects Irma and Matti Aaltonen), the Helsinki City Art Museum (1976, architect Tero Aaltonen), the Sara Hildén Art Museum in Tampere (1979, architects Asko Rasinperä / Pekka Ilveskoski), the Aine Museum in Tornio (1986, architect Matti Porkka) and the Saarijärvi Museum (1989, architects Laila Niemioja / Heikki Uusitalo). These museums are linked by their similar origins. The guiding impulse was a collection bequeathed to the city in question by significant local artist or patron, for which the city then built a home and agreed to pay for its running costs. These museums are small, 1,000-2,500 square metres in area, with exhibition spaces varying between 325 and 1,500 square metres. All six white buildings represent traditional Modernism, and the oldest pure Functionalism. The newer ones are combinations of "correct" and "good" elements 
trawled from important foreign museums. Together, these buildings form an archetype of the Finnish art museum.

When examining the hierarchical position of art museum buildings in the urban structure, together with the prestige of the institution they represent given substance in the form of a building, we find that the role of the art museum in Finland has been somewhat reserved while at the same time, however, searching for an independent identity. Before Kiasma, there was no desire to use art as an instrument of power. Nevertheless, art museums do have the 137 character of public buildings, and they do share a characteristic language. The modelling of exterior architecture, the arrangement of solid and windowed facades, textures (white brick, marble, and with Aalto also porcelain strips) and entrée areas, the junctures of indoor and outdoor space, staircases, and above all roof structures that deliver lighting from above underline the character of different spaces.

With art museums there was a greater opportunity than normal to find an individual

The Museum of Contemporary Art Kiasma, Helsinki. Architect Steven Holl, 1998. Photo: The Finnish National Gallery: the Central Art Archives / Ari Thiel.

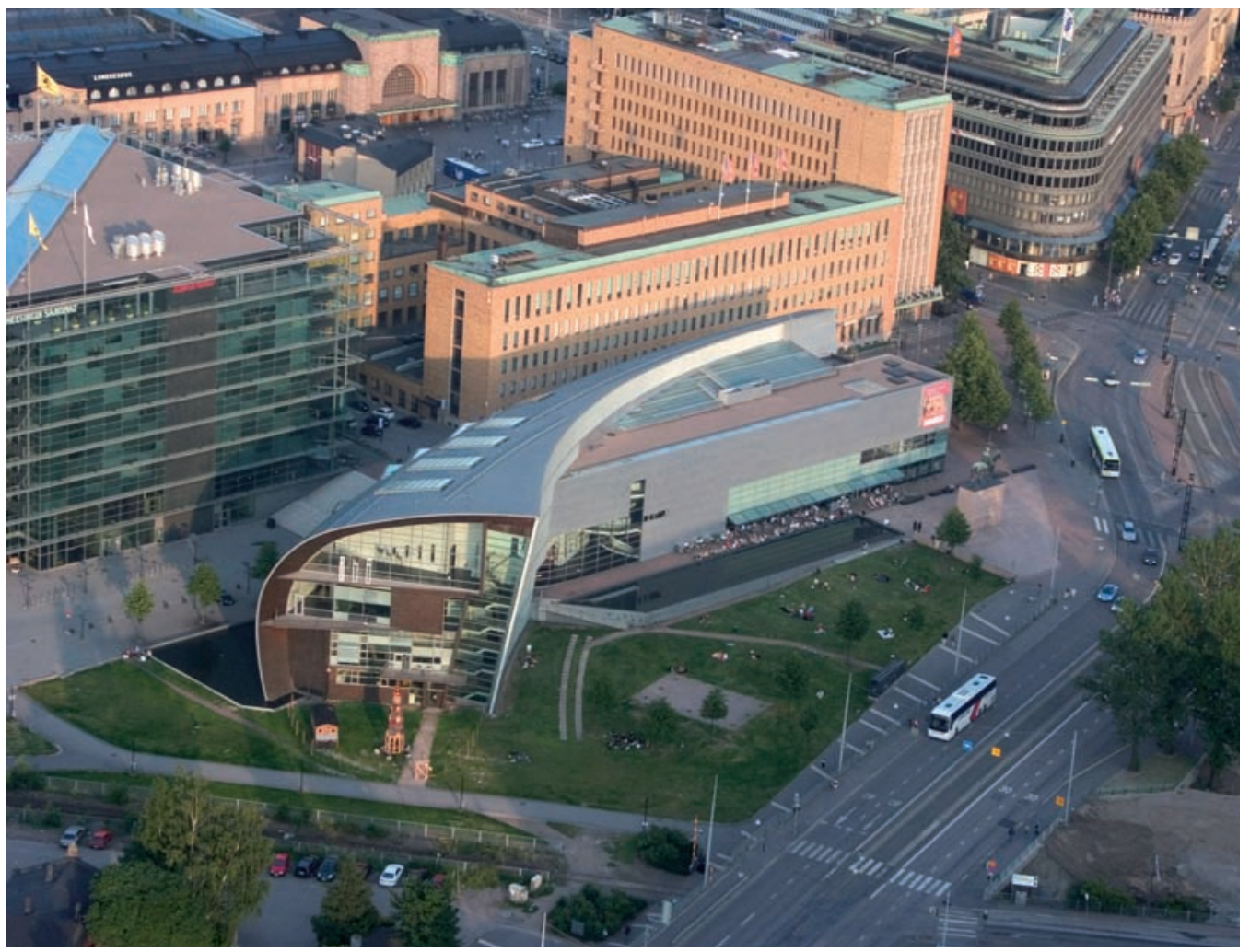


138 language, because there were few external pressures. Art museums still did not have a special status in the realm of social values nor did they have a precisely defined character. An out-of the-way site did not require the surrounding architecture to be taken account nor were architectural competitions organised. Outside the systems of social control, art museums' wish to remain independent as separate institutions was fulfilled and the client's requirement to create a building as a customised work, in other words "home" for a particular collection, became the most important influence on the design.

Curators and architects have had similar opinions of the character of the exhibition spaces, the so-called "white cubes". The exterior appearance simply has not interested the museum crowd; it has been left to the attention of patrons, decision-makers and architects. Moreover, the users of the museum simply have had no influence on the choice of location. Even so, it is apparent that behind both the finding of a museum location and the architectural elements there is a collective understanding of the kind of environment in which a museum should be situated and of what it should communicate. An analysis of this matter reveals that Ancient Greece and sites of worship of the Muses lie behind these solutions, even though direct references to the Acropolis are seldom found.

Water is a pervasive element in the location of Finnish art museums: the museums are typically situated by a lake, a river or the sea, just as ancient villas and palaces were. The ideal European museum of the post-war period stands by the two seas that delimit Europe, the Mediterranean and the Baltic. Not too far away from Finland is the Louisiana Museum in Denmark, which in one way or another is always referred to in connection with every museum project. And further south there is the Fondation Maeght on the French Riviera, which Finnish artists and patrons have enjoyed since the early eighteenth century.

In spite of the modest and "local" procedures, Finland's new art museum buildings communicate that they belong to an international family. They create an impression of how an art museum should look, they are like small pieces in an universal art space, which helps people to identify art at an early stage. The museums share an intimate atmosphere and a close connection with the surrounding cultural landscape. Low relief, asymmetry and adaptation to the natural terrain, as well as white colouring and sculpture park endeavours, easily lead to those ideals which were very open and prominent in the discussion of their time.

Aalto's design for the Tallinn Art Museum in 1937 was accepted as a realistic model in Finland. The design did not win, nor was the winning proposal ever built. ${ }^{3}$ The design was, however, immediately presented in architectural journals and it came up in all Finnish discussions of art museum architecture, the latest being in 1998. Aalto's proposal, which belongs to the same generation of Viipuri Library (1935) and the pavilion for the Paris World's Fair (1937), has become the ideal Finnish museum.

Still, as natural as it would be, I do not regard Pierre Bourdieu as my biggest guiding star, but his concept of the homo academicus does hit the mark. Bourdieu's analysis of the academic world seeks to objectify the competition in progress in this field. He uses the concept of the field instead of the generally used term profession, which he regards as too vernacular and as referring to the social subconscious of a roughly equally salaried group subscribing to a joint 
ethical set of rules. Bourdieu makes a clear distinction between the permanence of academic capital, based on the control of the means of replication, i.e. academic power lacking a scientific basis, and intellectual capital based on scholarly reputation. Present-day discussion and debate in the museum field also revolves in this sphere. $^{4}$

The study by Bourdieu ${ }^{5}$ is special in the sense that it combines conventional research requiring scientific objectification with a perspective on the objectifying subject itself. It is a reminder of how the objectifying subject is also objectified. I definitely agree with Bourdieu's observation: "The sharpest and most cruelly objectifying analyses are written with full knowledge of the fact that many of the objects concerned never come to think that the apparent cruelty of this or that sentence hurts its writer no less. They regard as unnecessary cruelty what in fact is only the recalling of things to memory."

In my own research, however, objectification has the goal of finding a subject, or subjects. I want to break down the myth of museum collections representing objective reality. None of the objects and artefacts in a museum represents reality any more, but rather a special world, the meta-reality maintained and cherished by museums. In addition to the fact that museum pieces have as their subjects their producers, makers and former owners and a specific history of their own, they will inevitably also have a special significance and meaning provided by the nature of the museum in question, and its personnel in particular, and bound to education and competence. There is no reason to deny or avoid this, nor to be ashamed of it.
NOTES

1. Marja-Liisa Rönkkö: Louvren ja Louisianan perilliset-suomalainen taidemuseo (Heirs of the Louvre and the Louisiana - Finnish Art Museums). Dimensio 2. Valtion taidemuseon tieteellinen sarja - Finnish National Gallery Research Series. Vammala 1999.

2. See also dissertation: Susanna Pettersson: Suomen Taideyhdistyksestä Ateneumiin - Fredrik Cygnaeus, Carl Gustaf Estlander ja taidekokoelman roolit (From the Finnish Art Society to the Ateneum Fredrik Cygnaeus, Carl Gustaf Estlander and the Roles of the Art Collection). Historiallisia Tutkimuksia 240. Suomalaisen Kirjallisuuden Seura / Dimensio 6. Valtion taidemuseon tieteellinen sarja. Hämeenlinna 2008.

3. KUMU - Art Museum of Estonia was designed by a Finnish architect after all: Pekka Vapaavuori won the competition and the new museum was opened in 2006.

4. Marja-Liisa Rönkkö: The Role of Museums. Form Function Finland. No 75-3/1999, pp 34-37.

5. Pierre Bourdieu - Loï J.D. Wacquant: Invitation to Reflexive Sociology. The University of Chicago Press, Chicago 1992.

*Marja-Liisa Rönkkö

PhD, Senior Lecturer in Museology

Address: University of Helsinki, Unioninkatu 38 D, PL 59, 00014 Helsingin yliopisto, Finland

E-mail:marja-liisa.ronkko@helsinki.fi 